\title{
舗装構造解析へのフォーリング・ウェイト・ デフレクトメーターの一利用*
}

PAVEMENT STRUCTURAL ANALYSIS USING FALLING WEIGHT DEFLECTOMETER

\author{
笠原 篤**.五十嵐光徳***
}

By Atsushi KASAHARA and Mitsunori IGARASHI

\begin{abstract}
This paper describes a method for evaluating a structural capacity of an asphalt pavement with falling weight deflectometer deflection data. A back-analysis was used to estimate in situ elastic moduli of a granular subbase and a subgrade in the pavement. A tensile strain at a bottom of the asphalt layer and a compressive strain in the subgrade surface under the standard wheel load were calculated with the BISAR. A number of allowable loading repetition corresponding to the tensile strain and the compressive strain were estimated with an asphalt strain criteria and a subgrade strain criteria obtained by many researchers.

The asphalt strain criteria was very useful imformation for a theoretical design method on asphalt pavements and overlay design, because there was a correlation between the cracking data and asphalt strain criteria in the national highway 337.

Keywords : bearing capacity, fatigue, FWD, permissible strain
\end{abstract}

\section{1. まえがき}

近年，アスファルト舗装の計画・設計・建設・維持・ 修繕・評価・研究・データバンクなどに関する種々の行 為を包括し，舗装を総合的にとらえる舗装マネジメント システム ${ }^{1) 2)}$ (Pavement Management Systems, 以下単 にPMS 进称する) が重要であるとの認識は, すでに世 界的に広まってきている3) 5). PMS は多くのサブシス テムから成り立っており, その中でも, 新設舗装ならび に既設舗装の維持・修䌜に関するライフサイクルコスト の算定のシステムがより重要となろう.そこでは, 新設 舗装のパフォーマンスおよび維持・修繥を施した舗装の パフォーマンス把握が不可欠となる。いうまでもなく, パフォーマンスは舗装のサービス性能 (Serviceablility) と 5 トン換算輪数（または年数）の関係のことを示して いる．舗装のサービス性能を表わす尺度として，「乗り 心地」を主体とした $\mathrm{PSI}^{6)}$ および $\mathrm{RCI}^{7)}$ がよく知られ ているが, わが国では「舗装の管理者からみた路面の損 傷」を主体とした $\mathrm{MCI}^{8)}$ で近年表現してきている。こ

* 土木学会第 39 回～第 43 回年次学術講演会にて一部発表

** 正会員 工博 北海道工業大学教授 土木工学科 ( T006 札幌市手稲区手稲前田 419-2)

*** 正会員 北海道開発局開発土木研究所維持管理研究室 ( 0060 札幌市豊平区平岸 1 条 3 丁目)
のように舗装をみる立場により, 舗装のサービス性能は 異なっている.しかし, サービス性能 $\left(S_{a}\right)$ は基本的に, 次のような関数として表現されると考えられよう ${ }^{9)}$.

$$
S_{a}=f(a, b, c, d, e, f)
$$

ここで, $a:$ 乗り心地

$b:$ すべり抵抗

$c$ : 路面の損傷

$d$ : 支持力

$e$ : 沿道住民に与える振動・騒音

$f:$ 路面の美観

ビの変数を重要視するかについては, 舗装のサービス 性能をどのような観点からとらえるかによって決められ るべきである. 高速道路, 国道, 街路, 生活道路など, その道路の利用のされ方および沿道条件など, 道路の性 格によって舗装のサービス性能は当然異なってくること から，主たる変数も異なる.

本研究においては, 舗装の支持力に着目し, 舗装のパ フォーマンスと支持力の関係を明らかにするとともに， フォーリング・ウェイト・デフレクトメーター（以下単 にFWDと称する）によるたわみ測定結果から，既設 舗装の寿命を推定する一手法について述べている. 


\section{2. $F \quad W \quad D$}

アスファルト舗装の支持力評価のための有力な手法に 非破壊試験の一種として, 従来から舗装表面でのたわみ 測定法がある。たわみ測定の精度向上，省力化などの点 から種々のたわみ测定装置が開発されてきているが10), 実車両の載荷条件との対応性, 層構造理論への適用性, さらに経済性などを総合的に検討し，現在入手できる装 置として FWD が最適であるとの報告も 1982 年に出さ れている11. 著者らも，この FWD に早い時期から注目 しており，1983 年12月にフェニックス社製のモデル PT 5002 を北海道工業大学に導入した (写真一1). そ のFWD の機構および特徵についての詳細は文献 12) に示されているので,ここでは省略するが, 荷重は 50 $\mathrm{kN}$, 載荷板半径は $15 \mathrm{~cm}$, たわ子測定位置は, 載荷板 中心, 載荷板中心からおのおの $300 \mathrm{~mm}, 750 \mathrm{~mm}$ 離れ た位置の計 3 か所である。わが国においても，FWDの 有用性が広く認められ，いくつかの機関にすでに導入さ れており，他のモデルのFWD も稼㗢中である(10).13).

\section{3. 路面損傷}

アスファルト舗装の路面損傷の 3 大要素は, (1)ひびわ れ，(2)わだち掘れ，(3)縦断山凸であり，おのおのそれら の定量的評価指標はわが国では定められている. 目視調 查, 簡単な機械による調查のほか, 高速で効率良くデー 夕を収集するために路面性状測定車が開発され，国道の すべての路線について多量のデータの蓄積が進められて いる.

路面損傷が生ずる要因は, 交通要因亡環境要因の $2 つ$ に大別される.

ひびわれにも種類が多く，施工ジョイントひびわれ， 低温横断ひびわれなどは温度要因より生ずる. 亀甲状ひ びわれは, 走行車雨によるアスファルト混合物層の疲労 に基づくものであり, 舖装破壊の究極的な現象の 1 つで ある。

わだち掘れは,アスファルト混合物層の流動（寒冷地 においてはスパイクタイヤなどによる摩耗も含まれる), 粒状路盤の塑性変形, 路床の塑性変形などに基づくもの

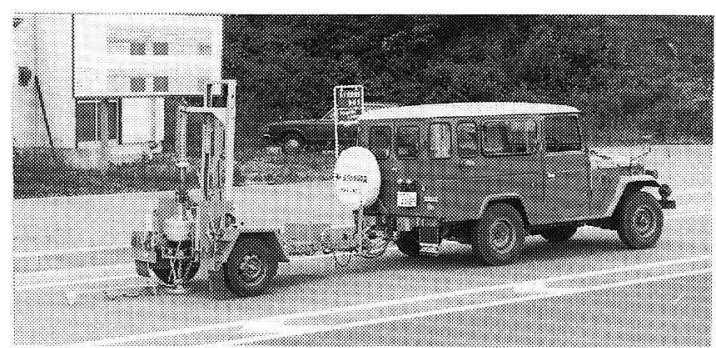

写真一1 フォーリング・ウェイト・デフレクトメーター
である。

縦断凹凸は, 路体の不等沈下, 路床・路盤の支持力の 不均一性, アスファルト混合物層のウェービングなどに 起因する.

これらの路面損傷は, 路面性状測定車により測定され たデー夕をもとに，ひびわれ率，わだち掘れ量，縦断凹 凸量を算出し，それらを総合した MCI で表現される。

\section{4. 調 査路線}

既設アスファルト舗装において，交通量が同一である にもかかわらず，亀甲状ひびわれが発生している区間之 ひびわれがみられない区間がある場合がある.従来では, 亀甲状ひびわれが発生している区間では，その支持力が 不足しているとの漠然とした認識でとビまっており, 詳 細な原因追求にまでは至っていない場合が多かった。

また既設アスファルト舗装の構造については，道路台 帳に記載されているはずであるが，特に舗装が古い場合 には，その舗装構造やオーバーレイの履歴が明確でない 場合も見受けられ，舖装構造さえ把握できないことがあ る. 舗装構造の確認には, コアボーリング, 掘削によら ざるを得ないが, 最近, 電磁波もしくは超音波を用いた 非破壊法などが開発されてきている ${ }^{14)}$.

ここでは，国道 337 号（北海道開発局札幌開発建設部 岩見沢道路事務所所管）の下り路線を選定し，FWDを 用いて, 距離程 30.500 -36.200 km の間 (北海道南幌町) の延長 $5.7 \mathrm{~km}$ について, 1988 年 11 月にたわみ測定を 行った。さらに, その対象区間について解体調査と道路 台帳の調査をし, 舖装構造の確認を行った. その結果延 長 $5.7 \mathrm{~km}$ の道路は6 6 区間に分けられた.おのおのの区 間を，区間 I（延長 $1.0 \mathrm{~km})$ ，区間 II $(1.1 \mathrm{~km})$ ，区間 III $(1.0 \mathrm{~km})$, 区間 $\mathrm{V}(0.6 \mathrm{~km})$, 区間 $\mathrm{V}(1.0 \mathrm{~km})$, 区 間V $(1.0 \mathrm{~km})$ とした。図一1 は調査区間を示したもの である。

図一2には各区間における舗装構造を示してある，解 体調査のみでは，路盤と凍上抑制層の使用材料が同一の 切込砂利であったことから，両者を区分することができ

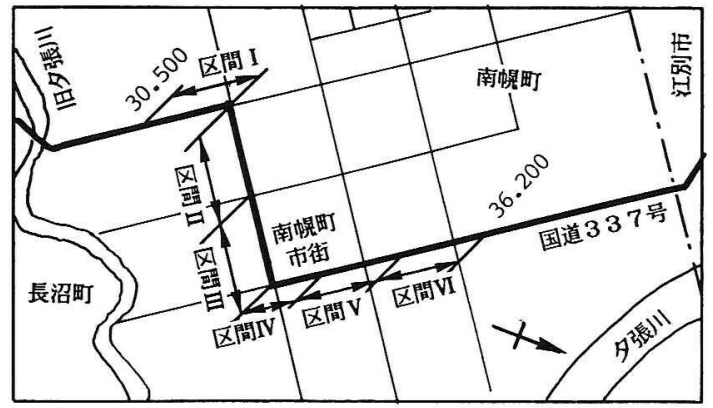

図一1 調査区間（国道 337 号） 


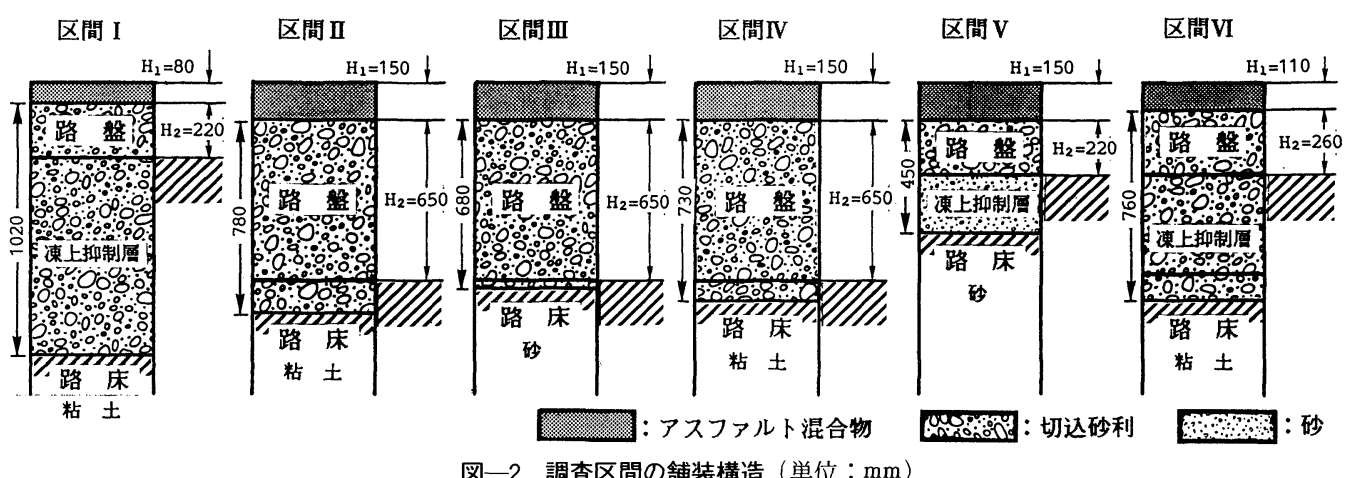

図一2 調查区間の舗装構造 (単位: $\mathrm{mm}$ )

ず，道路台帳により設計時の路盤厚を調査した．図一2 における各区間の右側に示してある路盤厚が設計値であ る. 後述するが，それを構造解析を行う場合の対象断面 とした。また区間 $\mathrm{I}$ ，区間 $\mathrm{V}$ ，区間 VIは，建設時には北 海道道であったが,その後国道に移管されたものである.

\section{FWD によるたわみ測定結果}

FWDによるたわみ測定において, 載荷板中心でのた わみの測定值を $d_{0}$, 載荷板中心から $300 \mathrm{~mm}$ 離れた地 点でのたわみの測定値を $d_{300}$, 載荷板中心から $750 \mathrm{~mm}$ 離れた地点でのたわみの測定值を $d_{750}$ として, ここで は表現している，おのおのの測定対象区間において 20 地点のたわみ測定を行った。それゆえ，各区間でのたわ み測定間隔は 35〜 50 m となる. 各区間において 20 の たわみデー夕が得られていることから，その区間のたわ みの代表值をいかなる值とするかが 1 つの問題となる. 通常平均值をもって代表値としがちであるが,ここでは, たわみの平均值 $(\bar{d})$ と標準偏差 $(\sigma)$ を求め, $d=\bar{d}+$ $1.28 \cdot \sigma$ をその区間のたわみの代表值 $(d)$ とした。すす わち，90 パーセンタイルたわみを代表值とした。表一1 は，たわみと路面性状デー夕（1987 年 10 月調査）を， 区間ごとにまとめたものである.

図一3 は，道路延長と路面性状デー夕 (100 m 間隔) およびたわみの実測值（35 50 m 間隔）の関係を図示 したものである，たわみ測定結果から，各区間の中でた わみの変動はあるが，表一1 からも区間ごとにたわみの 大きさが異なっていることがわかる.たわみの絶対值は， 舗装構成層の支持力 (舗装厚, 強度など), アスファル 卜混合物層の温度, 荷重の大きさ, 載荷時間, ひびわれ の有無などに依存するが，ここでたわみ測定対象とした 路線の舗装構成 (アスファルト混合物層厚, 路盤厚), 舗装温度 $\left(4.8 \sim 12.8^{\circ} \mathrm{C}\right)$, 荷重 $(4795 \sim 5047 \mathrm{kgf})$ を 総合的に勘案するならば，測定対象路線は，区間 I, 区 間 II ・III・IV，区間 V ・VIの 3 グループに分かれるよう である、特に，載荷板から離れた地点でのたわみ(ここ では $d_{750}$ ) は，路床の支持力を反映しているといわれて 表一1＼cjkstart各区間におけるたわみと路面性状データ

\begin{tabular}{|c|c|c|c|c|c|c|c|}
\hline & & 区間 I & 区間 II & 区間而 & 区間IV & 区間 V & 区間VI \\
\hline \multirow{3}{*}{$\begin{array}{c}\text { ひと割れ率 } \\
\text { (\%) }\end{array}$} & ひど割れ & 4.7 & 0 & 0 & 0 & 1.4 & 2.5 \\
\hline & バッチング & 15.7 & 0 & 0 & 0 & 0.1 & 0.7 \\
\hline & 合＼cjkstart計 & 20.4 & 0 & 0 & 0 & 1.5 & 3.2 \\
\hline \multirow{2}{*}{$\begin{array}{l}\text { わだち掘れ } \\
\text { 量 (mm) }\end{array}$} & 最 大 & 24 & 18 & 12 & 13 & 18 & 26 \\
\hline & 平均 & 16 & 14 & 10 & 10 & 13 & 21 \\
\hline 䋖断凹凸量 & (mm) & 3.93 & 1.25 & 0.97 & 0.32 & 2.84 & 2.82 \\
\hline \multicolumn{2}{|l|}{ MC I } & 3.8 & 6.6 & 7.4 & 7.4 & 6.3 & 4.9 \\
\hline \multicolumn{8}{|l|}{ たわみ } \\
\hline \multirow{3}{*}{$d_{\theta}$} & 標準偏差 & 0.110 & $\begin{array}{l}0.215 \\
0.067\end{array}$ & 0.041 & $\begin{array}{l}0.290 \\
0.030\end{array}$ & $\begin{array}{l}0.444 \\
0.109\end{array}$ & $\begin{array}{l}0.4063 \\
0.061\end{array}$ \\
\hline & 代表值 & 0.973 & 0.360 & 0.365 & 0.334 & 0.584 & 0.542 \\
\hline & 平均値 & 0.454 & 0.215 & 0.240 & 0.222 & 0.348 & 0.303 \\
\hline \multirow[t]{2}{*}{$d_{388}$} & 標準偏差 & 0.075 & 0.048 & 0.026 & 0.019 & 0.070 & 0.046 \\
\hline & 代表値 & 0.549 & 0.277 & 0.273 & 0.246 & 0.437 & 0.362 \\
\hline \multirow{3}{*}{$d_{758}$} & 平均值 & 0.258 & 0.140 & 0.147 & 0.139 & 0.242 & 0.173 \\
\hline & 標準偏差 & 0.051 & 0.026 & 0.012 & 0.010 & 0.041 & 0.033 \\
\hline & 代表 值 & 0.324 & 0.173 & 0.162 & 0.152 & 0.294 & 0.216 \\
\hline \multicolumn{2}{|l|}{ 荷重（kgf） } & 4,933 & 5,017 & 5,047 & 4,800 & 4,864 & 4,795 \\
\hline \multicolumn{2}{|c|}{ 舖装温度 $\left({ }^{\circ} \mathrm{C}\right)$} & 4.8 & 7.8 & 10.1 & 12.8 & 10.4 & 8.3 \\
\hline
\end{tabular}

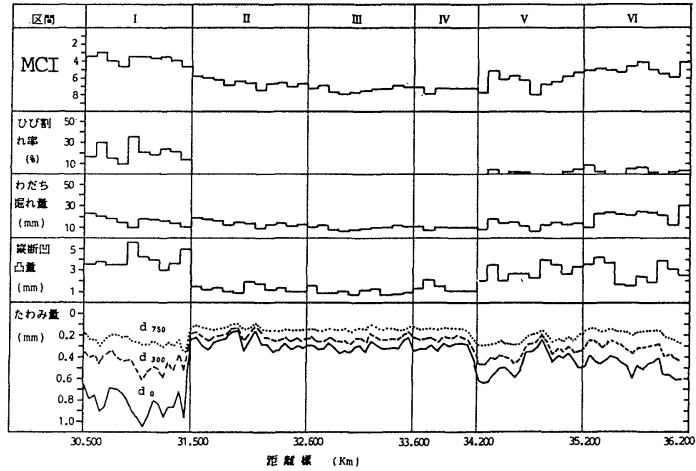

図一3路面性状データおよびたわみ測定結果

おり ${ }^{15)}$ ，表一1 が示しているように各グループごとに $d_{750}$ に差異があることがわかる.

\section{6. 舗装構成層の現地での弾性係数の推定}

アスファルト舗装の構造解析を行うにあたり，舗装構 成層の現地での弾性係数を推定することが必須となる. ここでは，たわみ測定結果と層構造の弾性理論解法プロ 
グラムの 1 つである BISAR を組み合わせ, 図解法を取 り入れた逆解析を行った。

舗装構成層の現地での弾性係数を推定するにあたって の手順は次のとおりである ${ }^{16)}$.

1）アスファルト舗装をアスファルト混合物層・路 盤・路床とから成る 3 層構造とする.ここでは, 凍 上抑制層を路床に含めている.

2）アスファルト層表面からポンチで深さ $40 \mathrm{~mm}$ ま で穿孔した穴底の温度を白金抵抗体で測定し，それ をアスファルト混合物層の代表温度とする ${ }^{17)}$.

3）室内における間接引張り試験から得られているア スファルト混合物の弾性係数とアスファルト混合物 層の弾性係数は，載荷時間が同一の条件下でよい対 応を示すことから ${ }^{16)}$, 図一4を用いアスファルト混 合物層の代表温度からアスファルト混合物層の現地 での弾性係数 (以下 $E_{1}$ と称する) を推定值とする.

交通履歴および温度履歴を受けたアスファルト混 合物の弾性係数に図一4 の関係が適用できるか否か については, 議論の多いところであろう.しかし, この種の問題については，いまだ完全には解明され ておらず，そ机自体がアスファルト舗装の分野で大 きな課題とされていることから，ここでは図一4が 適用できるものとして取り扱った。

4） FWD によるたわみ測定条件下で，BISARを用 いて, 路盤の現地での弾性係数 (以下 $E_{2}$ と称する) および路床の現地での弾性係数 (以下 $E_{3}$ と称する) を種々変化させ， 3 地点での理論たわみ $\left(\delta_{0}, \delta_{300}\right.$, $\delta_{750}$ ）を算出する.

5） $E_{2}$ および $E_{3}$ をパラメーターとし，横軸に載荷板 中心から $750 \mathrm{~mm}$ 離れた地点での理論たわみ（以下 $\delta_{750}$ と称する) を取り, 縦軸に載荷板中心から 300 $\mathrm{mm}$ 離れた地点での理論たわみ (以下 $\delta_{300}$ と称する)

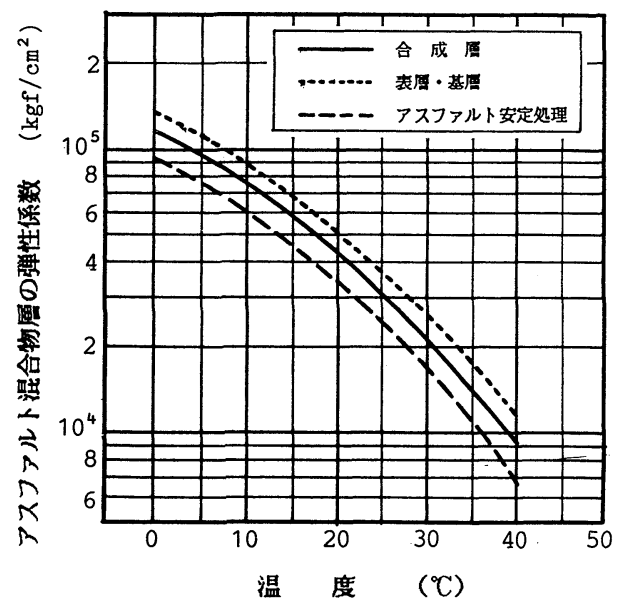

図一4温度とアスファルト混合物の弾性係数の関係
と $\delta_{750}$ との差, すなわち $\delta_{300}-\delta_{750}$ を取った理論た わみの曲線群を描く.

6) 理論たわみの曲線群に実測たわみの座標点 $\left(d_{750}\right.$, $\left.d_{300}-d_{750}\right)$ をプロットすることにより, 内挿法に より， $E_{2}$ および $E_{3}$ を推定する.

図一 5 は，区間 IIにおける $E_{2}$ および $E_{3}$ を推定するに あたっての理論たわみ曲線群の例を示したものである.

表一2 は, 各区間において推定された路盤の弾性係数 $\left(E_{2}\right)$ および路床の弾性係数 $\left(E_{3}\right)$ の一覧を示したも のである.なお, 表中のアスファルト混合物の弾性係数 は，たわみ測定時における舗装体の温度測定值から図一 4 の合成層（表層・基層用アスファルト混合物とアス ファルト安定処理を 1 つの層とみなした)の曲線により, 推定されたものである. 表一 2 より, 路盤の弾性係数は $2000 \sim 3700 \mathrm{kgf} / \mathrm{cm}^{2}$, 路床の弾性係数は $570 \sim 1070$ $\mathrm{kgf} / \mathrm{cm}^{2}$ と，各区間においてかなり異なっていることが 明らかとなった。

前述した手順に従い推定された各区間の $E_{2}$ および $E_{3}$ を用い，BISARにより FWD のたわみ測定条件下にお けるたわみを計算した結果と実測たわみの代表值を比較 した結果を表一 3 に示してある. 計算たわみと実測たわ みは比較的よい一致を示していることからここで推定 された舗装構成層の弾性係数は, ほぼ妥当であるとして もよいであろう。なお，ひびわれのある区間における載 荷板中心でのたわみに若干の差がみられることは， $E_{1}$

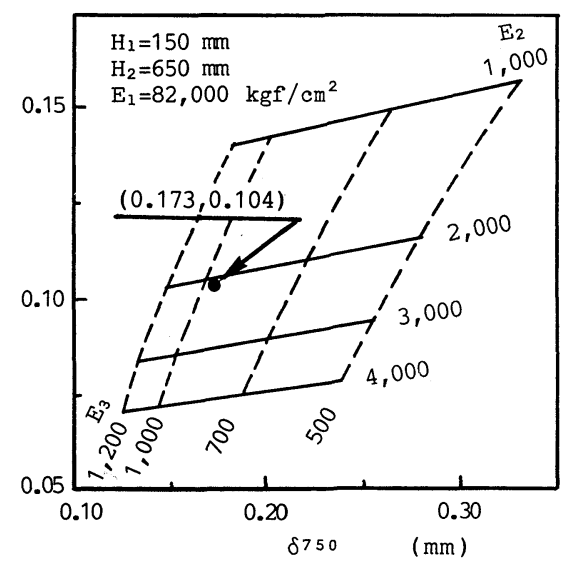

図一5 路盤・路床の弾性係数の推定の例（区間 II）

表-2 路盤・路床の弾性係数の推定値 $\left(\mathrm{kgf} / \mathrm{cm}^{2}\right)$

\begin{tabular}{cccr}
\hline 区間 & $\begin{array}{c}\text { アスファルト混 } \\
\text { 合物層 }\end{array}\left(\mathrm{E}_{1}\right)$ & $\begin{array}{c}\text { 路 盤 } \\
\left(\mathrm{E}_{2}\right)\end{array}$ & $\begin{array}{r}\text { 路 床 } \\
\left(\mathrm{E}_{3}\right)\end{array}$ \\
\hline I & 92,000 & 3,700 & 570 \\
II & 82,000 & 2,150 & 940 \\
III & 73,000 & 2,000 & 1,070 \\
IV & 63,000 & 2,700 & 980 \\
V & 72,000 & 2,650 & 600 \\
VI & 80,000 & 3,500 & 810 \\
\hline
\end{tabular}




\section{表一3 各区間における実測たわみと計算たわみの比較}

\begin{tabular}{ccccccc}
\hline & \multicolumn{7}{c}{ 区 } & 間 \\
& I & II & III & IV & V & VI \\
\hline $\mathrm{d}_{\oslash}$ & 0.973 & 0.360 & 0.365 & 0.334 & 0.584 & 0.542 \\
$\delta_{8}$ & 0.729 & 0.352 & 0.355 & 0.327 & 0.527 & 0.476 \\
$\mathrm{~d}_{308}$ & 0.549 & 0.277 & 0.273 & 0.246 & 0.437 & 0.362 \\
$\delta_{388}$ & 0.548 & 0.277 & 0.272 & 0.247 & 0.439 & 0.363 \\
$\mathrm{~d}_{758}$ & 0.324 & 0.173 & 0.162 & 0.152 & 0.294 & 0.216 \\
$\delta_{758}$ & 0.323 & 0.174 & 0.162 & 0.153 & 0.293 & 0.217 \\
\hline
\end{tabular}

注） $\mathrm{d} ：$ 実测たわみ、 $\delta:$ 計算たわみ（mm）

にひびわれの影響が含まれているとも考えられる.

\section{7. 構 造 評 価}

繰り返し作用する交通荷重に対するアスファルト舗装 の構造的耐久性の評価規準として, アスファルト混合物 層下面に生ずる引張りひずみ（以下 $\varepsilon_{R}$ と称する）に対 する許容載荷回数 (以下 $N_{A}$ と称する) と, 路床上面に 生ずる圧縮ひずみ（以下 $\varepsilon_{U}$ ヒ称する）に対する許容載 荷回数（以下 $N_{S}$ と称する）が, 現在提案されているア スファルト埔装の理論構造設計法においては, その基本 となっている18),19).

\section{（1） アスファルト混合物層の疲労抵抗性}

アスファルト混合物の疲労曲線については,これまで 数多くの研究者から提案されている. Per Ullidtz ${ }^{20)}$ に よる種々の研究成果の比較を図一6に示してあるが, 図 中には, 著者の成果 ${ }^{21)}$ もプロットしてある. アスファル ト混合物の夕イプ, アスファルト量, アスファルトの性 質などが若干異なるとしても, 疲労破壊自体の変動が大 きいことを考慮すれば，これらは比較的よい一致を示し ているといえる.なお, 図中のローマ数字については, 後述する.

\section{（2）路床の塑性変形抵抗性}

路床の塑性変形についても, $\varepsilon_{U}$ と $N_{S}$ の関係として, 多くの研究機関から提案されている. 図一7は, 諸外国 における種々の研究成果をPer Ullidtz ${ }^{20)}$ がまとめたも のであるが，わが国においてはこの種の研究は見当たら ない. $\varepsilon_{U}$ と $N_{S}$ の関係は, 提案している機関によってか なり異なっている. それは $N_{S}$ の定義が異なっているこ とに起因している. たとえば，PSI が 2 まで低下した ときの $N_{S}$ であったり, わだち掘れが $25 \mathrm{~mm}$ となるとき の $N_{S}$ であったりしている. $\varepsilon_{U}$ と $N_{S}$ の関係が図の上方 に位置しているグループは, PSI で定義されているも のであり，下方に位置しているグループは，わだち掘れ 量 $(13 \sim 30 \mathrm{~mm})$ で定義されているものである. これら の詳細については文献 20)に記述されているので, ここ では省略する.なお, 図中のローマ数字については, 後 述する。
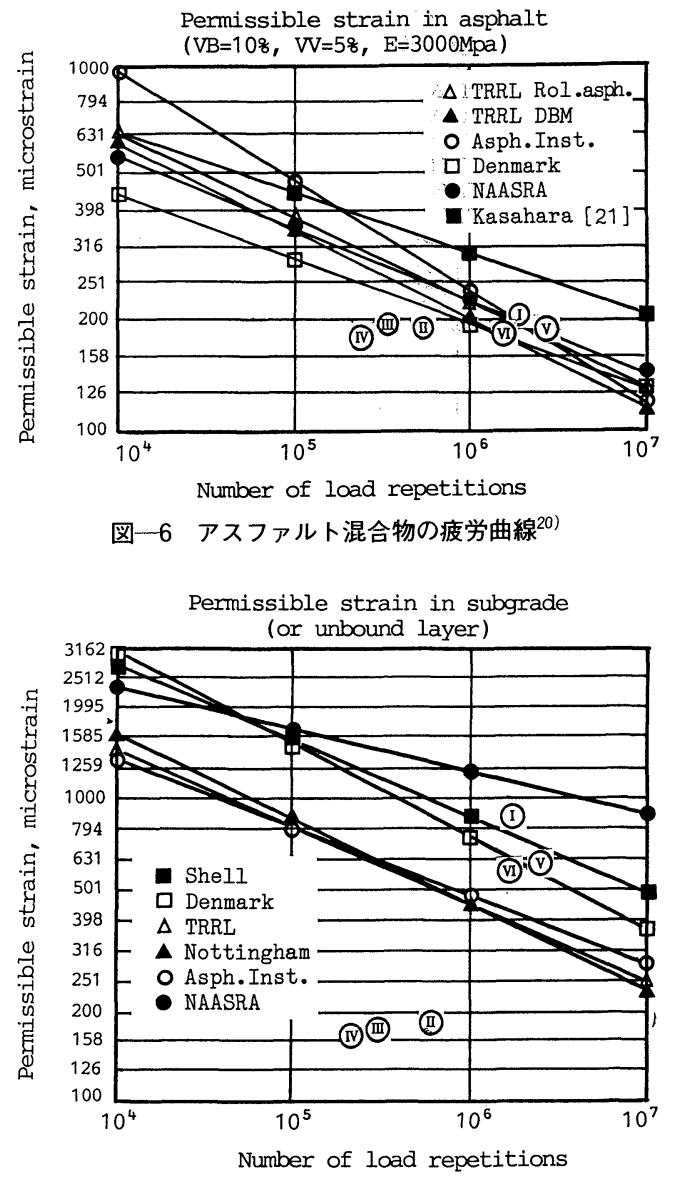

\section{図一7路床（または粒状路盤）の塑性変形に対する 許容載荷回数 ${ }^{20)}$}

\section{8. 舗装寿命の推定}

\section{（1）舗装構成層に生ずるひずみ}

ここでは，先に推定された各区間の $E_{2}$ および $E_{3}$ の 值を用いて, 大型車両が走行するときに舗装体に生じる $\varepsilon_{R}$ および $\varepsilon_{U}$ を BISARにより算出した. 計算条件とし て, 各層のポアソン比を 0.35 , 層間のすべりは粗とした. アスファルト混合物の弾性係数にいかなる值を採用する かが大きな問題となる.すなわち，アスファルト混合物 の疲労抵抗性は温度ならびに荷重履歴に依存することが 知られているが，ここではPer Ullidtz'20) がアスファル 卜混合物の疲労曲線を比較したときの条件と合致させ, アスファルト混合物層の弾性係数 $\left(E_{1}\right)$ を $30000 \mathrm{kgf} /$ $\mathrm{cm}^{2}$ とした。これは図一 4 から，ほぼ $25^{\circ} \mathrm{C}$ に対応する こととなる.

荷重条件としては, 輪荷重 $2500 \mathrm{kgf}$ の複輪, 接地半 径 $13.25 \mathrm{~cm}$, 接地圧 $4.5 \mathrm{kgf} / \mathrm{cm}^{2}$, 車輪中心間距離 34 cmである。 


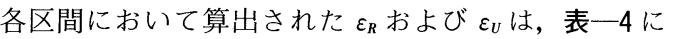
示されている.

\section{（2）交通量}

国道 337 号についての交通量調査データは, 1971 年 から 1987 年まであり, 総交通量（片側）は2 300 3400 台 / $12 \mathrm{~h}$ であった. また大型車混入率は 16～ 24 \%であったことから，5トン換算輪数は $217 〜 318$ 台／ 日と推定された。

各区間における 1987 年までの推定された累計 5 トン 換算輪数 $(N)$ は, 表一5のとおりである.

\section{（3）舗装構成層に生ずるひずみと繰返し載荷回数}

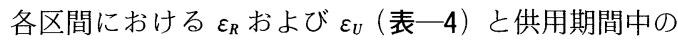
累計 5 トン換算輪数（表一5）との関係を, おのおの図 一6および図一7にプロットしてみた. 図中のローマ数 字は，各区間の番号を示している。

a) 路床の塑性変形

区間 II，III，IVにおける路床上面に生ずる圧縮ひずみ の值は約 $200 \times 10^{-6}$ とかなり小さく，路床の塑性変形が 問題となる繰返し 載荷回数は 1000 万回以上となる。一 方，区間 I, V , VIにおいては，路床の許容載荷回数を 上回るものもあり，特に区間 I では顕著である.このこ とから，これらの区間においては，路床の塑性変形がか なり進行しているものと推测される.

舗装のわだち掘れは，表面に現われる現象であること から，表層の流動，摩耗に注目されがちであるが，路床 の塑性変形に基づくものも含まれていることに注意する 必要があろう。

b) アスファルト混合物の疲労

区間 II , III, IV における $\varepsilon_{R}$ と $N$ の座標点は, アスファ ルト混合物の疲労曲線のかなり左側に位置しており, 疲 労曲線からみて, まだ疲労寿命は相当あるといえる：実 際に，これらの区間にはひびわれが発生していない（表

\begin{tabular}{|c|c|c|}
\hline 区間 & $\begin{array}{l}\text { アスファルト混合物層 } \\
\text { 下面の引張りひずみ }\end{array}$ & $\begin{array}{l}\text { 路床上面の } \\
\text { 圧繀ひずみ }\end{array}$ \\
\hline I & 206 & 889 \\
\hline II & 191 & 196 \\
\hline III & 197 & 185 \\
\hline IV & 170 & 179 \\
\hline $\mathrm{V}$ & 204 & 603 \\
\hline VI & 194 & 556 \\
\hline
\end{tabular}

\begin{tabular}{ccc} 
表 -5 & 累計 5 トン換算輪数 \\
\hline 区間 & 施工年 & 累計5ト換算輪数 \\
\hline I & 1971 & $1,746,000$ \\
II & 1983 & 584,000 \\
III & 1985 & 325,000 \\
IV & 1986 & 231,000 \\
V & 1964 & $2,411,000$ \\
VI & 1972 & $1,668,000$ \\
\hline
\end{tabular}

-1 参照）ことからしても，うなづけよう.

区間 I $\varepsilon_{R}$ と $N$ の座標点は, アスファルト混合物の 疲労曲線群の上方に位置している. さらに, 区間Vおよ びVの座標点も疲労曲線群の中央に位置している.これ らの座標点と疲労曲線との相対位置と実測のひびわれ率 （表一1）との間には相関がみられる.すなわち，座標 点が疲労曲線群の上方に位置しているものほど, ひびわ れ率が大きい.

路面調査において, ひびわれ率が大きい順は, 区間 I, VI，Vであり，ひびわれが発生していない区間はII，III， IVであることからして，ひびわれに関するパフォーマン スと疲労データとは, かなりよい相関があるといえる. すなわち，世界各国での実験により得られたアスファル 卜混合物の疲労曲線は, ある程度の変動があるもののひ びわれに関する舗装の寿命予測に有用であるといえる.

また, 図一6よりアスファルト混合物の許容載荷回数 を $2 \times 10^{6}$ 回程度とするには, アスファルト混合物層の 下面に生ずる引張り許容ひずみを $200 \times 10^{-6}$ 程度にする 必要があり, 許容載荷回数を $10^{7}$ 回程度とするには, ひ ずみを $125 \times 10^{-6}$ 程度にする必要があることがわかる. このように，アスファルト舗装の理論設計に必要なアス ファルト混合物層の疲労破壊回数を特定するには, さら に多くの路線について，ひびわれ率とアスファルト混合 物の疲労曲線との関係のデータを蓄積することが重要と なる。その蓄積が進めば，寿命予測に用いるべき疲労曲 線を特定することができ, アスファルト舗装の理論設計 およびオーバーレイ厚の理論設計が可能となるであろ う.

\section{9. 結 論}

本研究により得られた成果をまとめるとおよそ次のよ うになるであろう.

（1） FWD によるたわみデータを層構造弾性理論を 用いた逆解析により, 舗装構成層の現地での弾性係数を 推定することができた。

（2）アスファルト舖装のわだち掘れは，アスファル 卜混合物層の流動, スパイクタイヤによる摩耗, 粒状路 盤および路床の塑性変形に起因している.ここでは，路 床の塑性変形に基づくわだち掘れも無視することはでき ないことを明らかにした。

（３）アスファルト混合物層下面に生ずる引張りひず みと累計 5 トン換算輪数の座標点と, アスファルト混合 物の疲労曲線との相対位置は, 供用されているアスファ ルト舗装のひびわれ率と密接な関係がある.

(4) 世界各国での実験により得られたアスファルト 混合物の疲労曲線は, ある程度の変動があるものの, ひ びわれに関する舗装の寿命予測に有用であることが明ら 
かとなった．すなわち，アスファルト混合物層の疲労に 関する許容載荷回数の目安としては，ひずみ $200 \times 10^{-6}$ で $2 \times 10^{6}$ 回，ひずみ $125 \times 10^{-6}$ で $1 \times 10^{7}$ 回程度である としてもよいであろう.

\section{0. あとがき}

アスファルト舖装の合理的な寿命予測法，理論構造設 計法およびオーバーレイ厚設計法などを確立するうえで 必要なステップを述べてきたが，その過程において検討 すべき事項も多いと思われる.アスファルト舗装のひび われをもたらす疲労破壊回数の推定において, 現在まで の知見では有効桁数 2 を確保することも困難であろう し，破壊確率論的な考え方を導入することが必要となろ う.しかしながら，アスファルト舗装の理論設計へのア プローチの 1 つとしての手法を, 本研究で示すことがで きたと考えられる. 各ステップにおいてさらに詳細に議 論されるべき事項は多いが，それら自体が 1 つのテーマ となるほどのものであると考えられる.すなわち，ひび われが入った舗装のたわみ测定法をいかに考えるか, た わみから舗装構成層の弾性係数を推定するための逆解析 にビのような理論を用いるか（層弾性理論, 有限要素法, 粘弾性理論など), さらに静的解析か動的解析かなども 検討が必要であろう。また，荷重履歴および温度履歴を 受けている舖装構成層の弾性係数, 疲労抵抗性をよ゙のよ うにとらえるか, 舗装構成層に生ずるひずみを算出する 場合には標準荷重および標準温度を規定する必要がでて こよう.これら種々の問題をおのおの解決していかなけ ればならない.

本研究での手法を用い, 多くの路線についてひびわれ 率とアスファルト混合物の疲労曲線亡の関係のデータを 蓄積し, 寿命予測に用いるべき疲労曲線を特定すること により,アスファルト舖装の理論設計およびオーバーレ イ厚の理論設計が可能となるであろう.

最後に, 本論文の作成にあたり北海道大学助教授 姫 野賢治博士と討議させていただき, 多くの助言を受けた ことを記し，感謝申し上げる。

\section{参 考 文 献}

1) Haas, R. and Hudson, W. R. : Pavement Management Systems, Robert E. Krieger Publishing Company, Inc., Reprint Edition, 1986.

2) Hudson, W. R., Haas, R. and Pedigo, R. D. : Pavement Management System Development, NCHRP Report No.215, Transport Research Board, 1979.

3) Pavement Management Guide, Roads and Transportation Association of Canada, 1979.

4) Yeaman, J. and Lee, I. K. : A Handbook of Pavement Management, Vo. 1 and 2, Unisearch Ltd. and SAMI Pty. Ltd., Australia, 1979.
5) An OECD Scientific Expart Group : Pavement Management Systems, OECD, 1987.

6) Cary, W.N. and Irich, P.E. : The Pavement Serviceability-Performance Concept, HRB Bulletin, No. 250, 1960.

7) Pavement Management Guide, Road and Transportation Association of Canada, p.4.12, 1977.

8）飯島 尚・今井 博・猪股和義：MCI による舗装の供用 性の評価，土木技術資料，23-11，pp. 15 20，1981.

9）菊川 滋・笠原 篤：舗装マネジメントシステムにおけ るデータベースの役割と支持カデータの利用, 道路, 日本道路協会, pp. 53〜 58, 1987.9.

10）笠原 篤：非破壊試験としてのたわみ測定装置とたわみ データの利用, アスファルト, 第 160 号, 日本アスファ ルト協会, pp. 57〜68, 1989.

11) Hoffman, M.S. and Tompson, M. R. : Comparative Study of Selected Nondestructive Testing Devices, TRB 852, pp. 32 41, 1982.

12）笠原 篤・岳本秀人 · 伊藤保彦・古川真男 : フォーリン グ・ウエイト・デフレクトメータについて, 舗装, Vol. 20, No.6, pp. 15 19, 1985.

13）丸山輝彦・姫野賢治・林 正則：FWDによる埔装診断 システム, 舗装, Vol.23, No.11, pp.16〜20, 1988.

14) Berg, F., Jasen, J. M. and Ertman Larsen, H. J. : Structural Pavement Analysis Based on FWD, Georadar and/or Geosonar Data, Proceedings of 2nd International Conference on the Bearing Capacity of Roads and Airfields, pp. 453 461, England, 1986.

15) Molenaar, A.A.A. and van Gurp, Ch.A.P.M. : A Pavement Management System for Provincial Road in the Netherlands, Proceedings of 5th International Conference on Structural Design of Asphalt Pavements, Vol. 1, pp. 485 499, The University of Michigan, 1982.

16) Kasahara, A., Kubo, H. and Sugawara, T. : Estimation of In Situ Moduli of Pavement Structural Layer with Falling-Weight-Deflectometer Deflection Basin, Proceedings of 6 th International Conference on Structural Design of Asphalt Pavements, Vol. 1, pp. 590 596, The University of Michigan, USA, 1987.

17) Kennedy, C. K. : Pavement Deflection : Operating Procedures for Use in the United Kingdom, TRRL Report 835, 1978.

18) Shell pavement design manual-asphalt pavements and overlays for road traffic, Shell International Petroleum Company Limited, London, 1978.

19) Thickness Design-Asphalt Pavement Structures for Highway and Streets, 9th Edition, Asphalt Institute, 1983.

20) Per Ullidtz: Pavement Analysis, Elsevier Science Publishers B. V., 1987.

21）笠原 篤・岡川秀幸・菅原照雄：アスファルト混合物の 動的性状とその舗装構造の力学解析への利用, 土木学会 論文報告集，第 254 号，pp. 107 117， 1976.

(1989.8.17 • 受付) 